\title{
e-Participation Model for Kuwait e-Government
}

\author{
Zainab M. Aljazzaf ${ }^{1}$, Sharifa Ayad Al-Ali ${ }^{2}$, Muhammad Sarfraz ${ }^{3}$ \\ Department of Information Science, Kuwait University \\ Shdadiya, Kuwait
}

\begin{abstract}
Internet has an influence on every aspect of modern life. The increasing interest in e-government has led to increase in public expenditure on communication technologies. The technology provides and facilitates opportunities for citizens to interact with e-government, so called e-participation. In fact, it makes the citizens involvement higher in the delivery of services, administration, and decision making. People need to engage themselves and participate in e-government to achieve its objectives. e-Government literature explored the factors that influence people to participate in e-government. However, the study of e-participation is new in Kuwait. Therefore, this paper aims to find out the critical factors affecting e-participation in Kuwait. To attain the purpose of the research study, a conceptual model has been developed, keeping the context of Kuwait society in view. Then, a questionnaire has been designed and used to test the conceptual model. The results indicate that technical factors, social influence, political factors, perceived usefulness, and perceived ease-of-use are the significant factors that influence the citizen's intention to participate in Kuwait e-government. Consequently, the results of this study need to be adopted by the government to enhance e-participation in Kuwait e-government.
\end{abstract}

Keywords-e-Government; e-participation; e-participation factors; e-participation model; e-information; e-consultation

\section{INTRODUCTION}

In the recent years, societies have reached to very high levels of complexities, as compared to its past, in its day to day life. It has been highly surrounded by technology such as internet, computers, and mobile phones. Consequently, the high amount of work cannot be successfully achieved without the effective communication systems. It has been vital to make use of various technologies including Web and mobile networks. There is a growing trend among the citizens and public administrations to get along with the electronic life to communicate with each other conveniently.

e-Government is related to Information and Communication Technologies (ICTs) and it aims to develop the efficiency and quality of public administration [1]. eGovernment initiatives can be traced back to the 1960s, but in the late 1990s, the term e-government began to take form [2]. According to West [3], e-government is the use of internet or other digital means to deliver the government information and services online. Moreover, the United Nations described egovernment as "Utilizing the Internet and the world-wide-web for delivering government information and services to citizens" [4].

In the literature, e-government has been used occasionally to refer to e-participation [5]. Participation is related to community, public, and close in meaning to engagement, empowerment, and involvement [6]. The United Nations [7] expressed the e-participation as: provide citizens with greater e-information for decision making, promote e-consultation for the processes of participation and deliberation, and strengthen e-decision making through improving citizen input in decision making.

Moreover, the Organization for Economic Co-operation and Development (OECD) [8] defined e-participation as using ICT to support information delivery to citizens where this information is related to public policies and government activities. In general, participation is supported by ICT in government and governance for administration, policy making, decision making, and service delivery; where the users are citizens and customers [9].

e-Participation aims to attain many goals, such as: minimizing coordination and transaction costs in political and society relationships, better deliberativeness, promoting the ability of information-processing in information technology, raising e-information, enhancing e-consultation, and supporting e-decision making [6][10]. E-information, econsultation, and e-decision making are the three dimensions of e-participation framework [11].

Moreover, e-government and e-participation research assisted governments to refocus on the citizens, businesses, technologies, and tools, which lead to effective and efficient public administration systems [5]. e-Participation focuses on the development of ICTs which support participation in government processes [12]. For example, ICT tools that have been implemented in e-participation initiatives include emails, online discussion forums, online chat, online surveys, and group support systems [13].

United Nation Survey [14] measures e-participation index based on the e-participation framework dimensions: einformation, e-consultation, and e-decision-making, as shown in Table I. The table shows the leading countries in eparticipation, such as Denmark, Finland, and Republic of Korea. However, Kuwait has an e-participation index between 0.50 and 0.75 , which needs to be improved.

The main objective in e-participation is to achieve involvement and engagement of practitioners in decision making. This means that it is important to have high eparticipation from citizens in the government's portals where the online services and information are available.

e-Government literature explores the factors that affect eparticipation. However, the research work regarding eparticipation in Kuwait is relatively new. Therefore, this research is dedicated towards e-participation in Kuwait egovernment. Specifically, it identifies the reason behind 
people participation in e-government and seeks to find out factors which can influence e-participation in e-government in Kuwait. Consequently, it examines the following points:

1) What are the factors affecting e-participation in Kuwait?

2) Does Kuwait have a low level of e-participation in egovernment portal and why?

3) How to attract citizens and residents to participate in egovernment portal?

The rest of the paper is organized, as follows: The related work is presented in Section II. Section III discusses the research methodology. Data analysis and discussion is presented in Section IV and Section V, respectively. Section VI concludes the paper.

TABLE. I. E-PARTICIPATION INDEX TOP 5 COUNTRIES IN 2018 [14]

\begin{tabular}{|l|l|l|}
\hline Rank & Country & Name \\
\hline 1 & Denmark & 1 \\
\hline 1 & Finland & 1 \\
\hline 1 & Republic of Korea & 1 \\
\hline 4 & Netherlands & 0.9888 \\
\hline 5 & Australia & 0.9831 \\
\hline 5 & Japan & 0.9831 \\
\hline 5 & New Zealand & 0.9831 \\
\hline 5 & Spain & 0.9831 \\
\hline 5 & United Kingdom of Great Britain and Northern Ireland & 0.9831 \\
\hline 5 & United States of America & 0.9831 \\
\hline
\end{tabular}

\section{RELATED WORK}

Allowing citizens to interact with government through eparticipation faces many critical issues. Several studies were done to examine the factors affecting e-participation [15]-[22]. In fact, many studies have found the factors that influence citizens' engagement in e-government services and eparticipation models.

Colesca and Dobrica, [23] explored the factors that affect citizens' adoption of e-government services in Romania. They have used Technology Acceptance Model (TAM) and realize that citizen's higher perception of usefulness, ease of use, quality, and trust of e-government services directly enhanced their satisfaction and implicitly the level of adoption of egovernment.

Reddick [15] examined citizen interaction with egovernment using three e-participation models. They used quantitative method (Survey) and found out that citizens have mostly used e-participation for management activities and less for consultative and participatory activities. Moreover, the factors that affect e-participation level are: demand by citizens for e-government, the digital divide, and political factors.

Macintosh [11] presented three factors that affect eparticipation. These are ICT infrastructure, human capital, and governance. The ICTs infrastructure is measured by the indicators: PCs, Internet users, telephone lines, online population, mobile phones, and TVs. The indicated capital is measured by education, income, productivity, skills and knowledge.

Moreover, a study in Zambia [18] stated that there are many factors that affected adoption of e-government where ICT has been employed to sustain e-government initiatives. The paper assessed the issues, opportunities, and challenges at the same time with the e-government adoption criteria. The findings reported that the factors that led to delay in the adoption of e-government in Zambia are due to lack of adequate ICT infrastructure and political will, lack of appropriate change management procedures, provision of content in English other than local languages, and noncontextualization of e-government practices.

Millard, Nielsen, Warren, Smith, and Macintosh [13] identified factors affected e-participation in Singapore and determined many factors which are divided in two groups. The first group is called access factors, it includes infrastructure, platforms, website accessibility, financial assistance, and access to e-service. The second group is called knowledge and involves international collaboration, knowledge training, and content availability. Furthermore, a significant study in [17] maps the factors that shape the development of e-participation. It developed an analytical framework to recognize the key variable, internal factors, and external factors. The internal factors are top-level impacts, middle level outcomes, base level operational outputs and raw material. The external factors are political culture, public service culture, legal environment, policy environment, autonomy, technology, and socio-economic environment.

Stoiciu [20] stated that according to various studies and surveys by different organizations in many countries, there are problems in implementing e-participation. However, strengthening e-participation faces four types of barriers, which are: Political Barriers, social barriers, technology barriers, and human/emotional barriers.

The study concluded with four solutions to engage citizens, benefits of citizen inclusion, and better eparticipation tools, as follows: (a) Involvement of the civil society in decision making power to develop the value of associative life and democratic systems, (b) Better use of resources and the appropriate development arise as the effectiveness and the quality of the governance increase, (c) Empowerment of citizens should be supported by public authorities and non-government organizations community who organize interventions, (d) Better motivations where adequate and long-term participation needs that regional and local governments and authorities involve in a transparent and open process.

Ahmad, Markkula, and Oivo [24] explored the factors that influenced end-user adoption of e-government services in Pakistan. The research work is based on Unified Theory of Acceptance and Use of Technology (UTAUT) model. It finds that performance of expectancy; effort expectancy, facilitating conditions, and social influence are the factors that affect citizen's adoption of e-government services in Pakistan. As a result, they realize that it is important to understand citizens' needs, run advertising campaigns to increase citizens' 
awareness, present the role of citizens, and raise the users' confidence in the system.

Ali and Ali [21] investigated the factors that affect citizen's acceptance and readiness to use e-participation tools in Kingdom of Bahrain. These factors are optimum, innovation, insecurity, and discomfort. They used Technology Readiness Acceptance (TRA) model, which combined TAM and Technology Readiness Index (TRI) to find out the positive and negative aspects regarding the technology beliefs. As a result, optimism and innovation affect usefulness and ease of use factors while insecurity and discomfort did not affect usefulness factor. However, insecurity does not affect ease of use factor.

AlAwadhi and Morris [25] studied the factors that influence the acceptance of Kuwait e-government services, making e-government initiatives success depends on two points; government support and the adoption of e-government services by citizens. The authors used the UTAUT model and found the factors that influence the acceptance of egovernment services. The factors are linked to technology issues, lack of awareness, usefulness, ease of use, cultural and social influences, and reforming bureaucracy.

Aljazzaf [26] studied the factors influencing people in Kuwait to trust e-government. The author developed a model and tested it through a survey. The result showed that factors such as perceived usefulness, security, perceived ease of use, and Website quality affect people in Kuwait to trust and use egovernment.

The presented researches express various factors that affect e-participation. The work, in this paper, aims to find out about factors that affect e-participation in e-government in Kuwait. This study proposes the factors influencing eparticipation in Kuwait in concern to many previous studies.
Consequently, a model is built to identify the critical factors to help increase participation in e-government and improve citizen's satisfaction in Kuwait e-government.

\section{RESEARCH Methodology}

This section presents the data methodology and includes the proposed research model and questionnaire.

\section{A. The Proposed Research Model}

This section presents the research proposed model, as shown in Fig. 1. The figure displays all the factors and relationships among them that represent the hypotheses. The model places the constructs used by TAM model, extracted from the literature, and other factors that are mostly related to Kuwait culture. The factors are the technical, demographic, social influence, political, perceived quality, perceived usefulness, perceived ease of use, and intention to participate.

The following presents the discussion of the factors in the research proposed model and the hypotheses:

1) Technical factors: Technical factors refer to the website design and content, channel of communication, and infrastructure. In fact, having good technical factors lead to better e-government services, lower cost, and reduce wastage. First, Website design and content impact the users experience and how they interact with the website. The more clear, easy, and simple website design the more users enter and use the services.

Second, using channels of communication which are classic such as telephone, email, Fax, and SMS; and the other communication channels used by most young users like; social media, television, radio, and mobile apps. Knowing which communication channel(s) the users preferred is important to easily connect with the government.

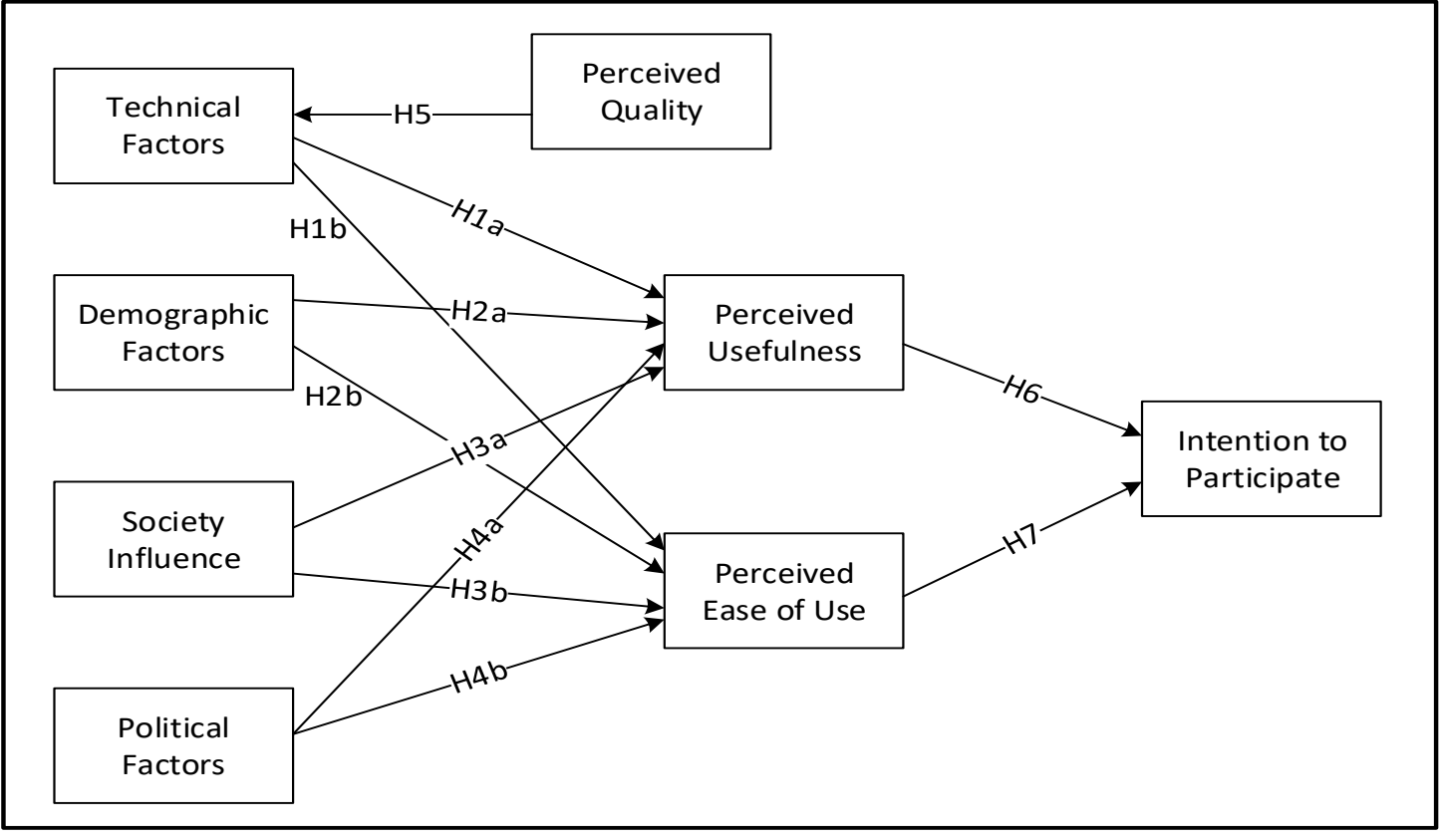

Fig. 1. The Research Model. 
Third, the infrastructure refers to the hardware, software, network resources, and servers. It allows the government to deliver the services to users in the best possible way. Technology infrastructure is important in the success of the egovernment. However, good infrastructure saves users and government time, money, and effort. The following are the hypotheses which assigned to the technical factors.

- H1a: Technical factors are positively related to perceived usefulness.

- H1b: Technical factors are positively related to perceived ease of use.

2) Demographic factors: Demographic factors are the characteristics of the population expressed statistically such as; the gender, education level, internet experience, and occupation. Demographic is used by government and other institutions to help understand people's characteristics more clearly. Therefore, the following are the hypotheses which presented the demographic factors.

- H2a: Demographic factors have influence on perceived usefulness.

- H2b: Demographic factors have influence on perceived ease of use.

3) Social influence: Social influence is an important factor especially in Kuwait culture. It is the persuasive influence we have on one another. Many users change their view about a new system because of the effect that a person does on others, such as their peers and respected superiors. The following are the social influence hypotheses.

- H3a: Social influence is positively related to perceived usefulness.

- H3b: Social influence is positively related to perceived ease of use.

4) Political factor: The political factor is the level of trust in government, government commitment, and the political party affairs, which have effect on the user's intention to eparticipate. This leads to the following hypotheses:

- H4a: Political factors are positively related to perceived usefulness.

- H4b: Political factors are positively related to perceived ease of use.

5) Perceived quality: Using a high quality system increases the technical factors quality. Examples of quality measures include Website usefulness and accuracy. Therefore, this leads to the following hypothesis:

- H5: Perceived quality is positively related to Technical factors.

6) Perceived usefulness: The more the system enhances citizen's job performance the more citizens will go for electronic participation, Therefore, this leads to the following hypothesis:
- H6: Perceived of usefulness is positively related to eparticipation level.

7) Perceived ease of use: More the system saves effort; more the citizens will go for electronic participation. Therefore, this leads to the following hypothesis:

- H7: Perceived ease of use is positively related to eparticipation level.

Table II summarizes the hypotheses and their description.

\section{B. The Research Questionnaire}

After developing the research model, a questionnaire has been designed and the data collected. The first task done here was designing the questionnaire to match the questions to the factors.

The questionnaire was developed to experimentally verify the proposed model and gather the necessary information. The questionnaire is divided into sections. Each section has a set of questions that refers to a factor in the model.

This study surveyed various groups of citizens and residents to get their point of view about Kuwait egovernment portal, their experience, and their intension to participate on e-government portal.

TABLE. II. THE RESEARCH HYPOTHESES

\begin{tabular}{|c|c|c|}
\hline $\mathbf{N}$ & Hypothesis & Description \\
\hline H1a & $\begin{array}{l}\text { Technical factors is } \\
\text { positively related to } \\
\text { perceived usefulness }\end{array}$ & $\begin{array}{l}\text { Having better technical factors lead to } \\
\text { better job performance. }\end{array}$ \\
\hline $\mathrm{H} 1 \mathrm{~b}$ & $\begin{array}{l}\text { Technical factors is } \\
\text { positively related to } \\
\text { perceived ease of use }\end{array}$ & $\begin{array}{l}\text { Having excellent technical factors save } \\
\text { effort. }\end{array}$ \\
\hline $\mathrm{H} 2 \mathrm{a}$ & $\begin{array}{l}\text { Demographic factors } \\
\text { have influence on } \\
\text { perceived usefulness }\end{array}$ & $\begin{array}{l}\text { Gender, education level, internet } \\
\text { experience, and occupation influence the } \\
\text { job performance. }\end{array}$ \\
\hline $\mathrm{H} 2 \mathrm{~b}$ & $\begin{array}{l}\text { Demographic factors } \\
\text { have influence on } \\
\text { perceived ease of use }\end{array}$ & $\begin{array}{l}\text { Gender, education level, internet } \\
\text { experience, and occupation influence the } \\
\text { effort spent in using the system. }\end{array}$ \\
\hline $\mathrm{H} 3 \mathrm{a}$ & $\begin{array}{l}\text { Social influence is } \\
\text { positively related to } \\
\text { perceived usefulness }\end{array}$ & $\begin{array}{l}\text { The more peers and respected superiors } \\
\text { who have positive experience using a } \\
\text { system the more new users will exist. }\end{array}$ \\
\hline $\mathrm{H} 3 \mathrm{~b}$ & $\begin{array}{l}\text { Social influence is } \\
\text { positively related to } \\
\text { perceived ease of us }\end{array}$ & $\begin{array}{l}\text { The more peers and respected superiors } \\
\text { who have positive experience using a } \\
\text { system the more users will save effort. }\end{array}$ \\
\hline $\mathrm{H} 4 \mathrm{a}$ & $\begin{array}{l}\text { Political factors is } \\
\text { positively related to } \\
\text { perceived usefulness }\end{array}$ & $\begin{array}{l}\text { The more a citizen trust in government } \\
\text { the more the user will believe that the } \\
\text { system enhance his/her job. }\end{array}$ \\
\hline $\mathrm{H} 4 \mathrm{~b}$ & $\begin{array}{l}\text { Political factors is } \\
\text { positively related to } \\
\text { perceived ease of use }\end{array}$ & $\begin{array}{l}\text { The more a citizen trust in government } \\
\text { the more the user will believe that using } \\
\text { the system will save effort. }\end{array}$ \\
\hline H5 & $\begin{array}{l}\text { Perceived quality is } \\
\text { positively related to } \\
\text { technical factors }\end{array}$ & $\begin{array}{l}\text { Using a high quality system increase the } \\
\text { technical factors quality. }\end{array}$ \\
\hline H6 & $\begin{array}{l}\text { Perceived usefulness is } \\
\text { positively related to e- } \\
\text { participation level }\end{array}$ & $\begin{array}{l}\text { The more the system enhance citizen`s } \\
\text { job performance the more citizens will } \\
\text { go for electronic participation. }\end{array}$ \\
\hline $\mathrm{H} 7$ & $\begin{array}{l}\text { Perceived ease of use is } \\
\text { positively related to e- } \\
\text { participation level }\end{array}$ & $\begin{array}{l}\text { The more the system saves effort the } \\
\text { more the citizens will go for electronic } \\
\text { participation. }\end{array}$ \\
\hline
\end{tabular}


The questionnaire consists of 38 questions, easy and clear for participants to answer, as shown in Appendix 1. The first part includes questions regarding demographic factors such as age, gender, and familiarity with internet. Other questions are regarding the proposed e-participation factors. The questions are measured on a five-point scale of "Strongly disagree" to "Strongly agree". For example, Part C of the questionnaire presents the technical factors. It includes six questions about the web portal usage, contents, and internet, as shown in Table III.

The questionnaire was conducted using a professional survey website SurveyMonkey. The questionnaire was distributed online only via Twitter, WhatsApp and email. The target population of the study was chosen to be the citizens and residents of Kuwait. These were selected as the questionnaire population because they are the main users of Kuwait e-government portal. Also, knowing their point of view about the Kuwait e-government will help improving it. Initially, the questionnaire was pretested to an appropriate sample of 15 people varying in gender, age, occupation, education level, and internet usage to make sure that it is applicable for distribution. More importantly, it was translated into Arabic and opened for a month from April 13 to May 12, 2015. During this period of time, as many as 508 responses were received.

TABLE. III. THE TECHNICAL FACTOR IN THE QUESTIONNAIRE

\begin{tabular}{|l|l|}
\hline C. & \multicolumn{2}{|c|}{ Technical Factor } \\
\hline 1 & Registration in the portal is easy \\
\hline 2 & Using the e-government portal is easy \\
\hline 3 & The e-government portal involves many important services \\
\hline 4 & The services provided online make the procedures easier and simple \\
\hline 5 & The government services provided online are of high quality \\
\hline 6 & Weak internet in Kuwait prevents citizens from the portal usage \\
\hline
\end{tabular}

\section{DATA ANALYSIS AND FINDING}

This part presents the analysis of the data collected through the online survey. As many as 508 persons have responded to the questionnaire and only 188 completed it. Table III presents the respondents' profile that represents the respondents' gender, age, level of education, occupation, internet experience, and familiarity with e-government portal. For example, Table IV shows that $51.77 \%$ of respondents are females, while $48.23 \%$ are males. Hence, Moreover, number of females responded was more than males. Moreover, $51.18 \%$ of respondents are between 18-29 years old.

In addition, $65.75 \%$ of respondents have bachelor degrees and most of them $59.25 \%$ are employees. Nearly half of the respondents $42.72 \%$ are very familiar with internet, and only $1.97 \%$ are not familiar with e-government.

To validate the hypotheses, different tests are conducted. These tests are: T-Test, One-way ANOVA, and Correlation. For example, to test the hypothesis H1a, correlation was used with Technical factors and perceived usefulness. The results of the Correlations are displayed in Table V. Correlation is significant at the 0.01 level (2-tailed). The value of Sig is .000 $<0.01$. Therefore, based on the Correlation test, there is a strong positive relationship (0.761) between technical factors and usefulness, hence H1a is accepted.

To test the gender, T-Test is required. Table VI presents Ttest for Gender. Based on the means results, there are no differences in means. Therefore, Gender has no influence on perceived usefulness.

To test the Age, a one-way ANOVA was used with Age and usefulness. The results of the ANOVA are displayed in Table VII and Table VIII. Sig value is .637> .05 and there are no differences in means, therefore age has no influence on perceived usefulness.

Similar to Tables V to VIII, other tables are not shown here due to brevity. However, overall findings are summarized in Table IX. The table shows the hypotheses and the relationship strength between the factors. In addition, it shows whether the hypotheses are accepted or rejected.

TABLE. IV. RESPONDENTS’ PROFILE

\begin{tabular}{|c|c|}
\hline Variable & Percentage \\
\hline \multicolumn{2}{|l|}{ Gender } \\
\hline Male & $48.23 \%$ \\
\hline Female & $51.77 \%$ \\
\hline \multicolumn{2}{|l|}{ Age } \\
\hline $18-29$ & $51.18 \%$ \\
\hline $30-39$ & $27.76 \%$ \\
\hline $40-49$ & $13.78 \%$ \\
\hline 50-Above & $7.28 \%$ \\
\hline \multicolumn{2}{|l|}{ Education } \\
\hline Secondary & $10.04 \%$ \\
\hline Diploma & $16.93 \%$ \\
\hline Bachelor & $65.75 \%$ \\
\hline Master and above & $7.28 \%$ \\
\hline \multicolumn{2}{|l|}{ Occupation } \\
\hline Student & $24.41 \%$ \\
\hline Employee & $59.25 \%$ \\
\hline Business owner & $3.35 \%$ \\
\hline Retired & $7.28 \%$ \\
\hline Not Working & $5.71 \%$ \\
\hline \multicolumn{2}{|c|}{ Familiarity with internet } \\
\hline Very Familiar & $42.72 \%$ \\
\hline Fairly Familiar & $38.39 \%$ \\
\hline Familiar & $16.93 \%$ \\
\hline Not Familiar & $1.97 \%$ \\
\hline \multicolumn{2}{|c|}{ Familiarity with e-government } \\
\hline Very Familiar & $10.04 \%$ \\
\hline Fairly Familiar & $27.56 \%$ \\
\hline Familiar & $37.60 \%$ \\
\hline Not Familiar & $24.80 \%$ \\
\hline \multicolumn{2}{|c|}{ Use e-government portal } \\
\hline Yes & $53.15 \%$ \\
\hline No & $46.85 \%$ \\
\hline
\end{tabular}


TABLE. V. CORRELATIONS BETWEEN TECHNICAL FACTORS AND PERCEIVED USEFULNESS

\begin{tabular}{|l|l|l|l|}
\hline \multicolumn{2}{|l|}{ Correlations } & Technical Factors & $\begin{array}{l}\text { Perceived } \\
\text { Usefulness }\end{array}$ \\
\hline $\begin{array}{l}\text { Technical } \\
\text { Factors }\end{array}$ & $\begin{array}{l}\text { Pearson } \\
\text { Correlation }\end{array}$ & 1 & $.761^{* *}$ \\
\hline & Sig. (2-tailed) & & .000 \\
\hline & N & 188 & 188 \\
\hline $\begin{array}{l}\text { Perceived } \\
\text { Usefulness }\end{array}$ & $\begin{array}{l}\text { Pearson } \\
\text { Correlation }\end{array}$ & $.761^{* *}$ & 1 \\
\hline & Sig. (2-tailed) & .000 & 188 \\
\hline & N & 188 & $*$ Correlation is significant at the 0.01 level (2-tailed). \\
\hline & & \multicolumn{2}{l}{} \\
\hline
\end{tabular}

TABLE. VI. T-TEST FOR GENDER

\begin{tabular}{|l|l|l|l|l|l|}
\hline $\begin{array}{l}\text { Demographic } \\
\text { Factors }\end{array}$ & N & Mean & T & df & $\begin{array}{l}\text { P.value } \\
\text { (sig2tailed) }\end{array}$ \\
\cline { 1 - 5 } Gender & 87 & 18.09 & -.556 & 186 & .579 \\
\hline Male & 101 & 18.41 & -.545 & 158.34 & .587 \\
\hline Female &
\end{tabular}

The results show that all the hypotheses are accepted except for two, which are $\mathrm{H} 2 \mathrm{a}$ and $\mathrm{H} 2 \mathrm{~b}$. It represents that there is no influence of demographic factors on perceived usefulness and ease of use. Other hypotheses are accepted, which represent the influence between the factors within the hypotheses with different influence rates. For example, based on the Correlation test, there is a strong positive relationship (0.713) between technical factors and ease of use, therefore, $\mathrm{H} 1 \mathrm{~b}$ is accepted. Furthermore, based on the Correlation test, there is a strong relationship (.702) between perceived usefulness and intention to participate, thus, H6 is accepted. Although $\mathrm{H} 4 \mathrm{~b}$ is accepted, but there is a very weak relationship between political factors and ease of use.

TABLE. VII. ONE-WAy ANOVA For AGE AND PERCEIVEd USEFUlNess

\begin{tabular}{|l|l|l|l|l|l|}
\hline $\begin{array}{l}\text { Perceived } \\
\text { Usefulness }\end{array}$ & $\begin{array}{l}\text { Sum of } \\
\text { Squares }\end{array}$ & Df & $\begin{array}{l}\text { Mean } \\
\text { Square }\end{array}$ & F & Sig \\
\hline $\begin{array}{l}\text { Between } \\
\text { Groups }\end{array}$ & 27.129 & 3 & 9.043 & .568 & .637 \\
\hline Within Groups & 2929.57 & 184 & 15.922 & - & - \\
\hline Total & 2956.70 & 187 & - & - & - \\
\hline
\end{tabular}

TABLE. VIII. DESCRIPTIVE TABLE FOR AGE

\begin{tabular}{|c|c|c|c|c|c|}
\hline \multirow{2}{*}{$\begin{array}{l}\text { Perceived } \\
\text { Usefulness }\end{array}$} & \multirow{2}{*}{$\mathbf{N}$} & \multirow{2}{*}{ Mean } & \multirow{2}{*}{$\begin{array}{l}\text { Std. } \\
\text { Dev. }\end{array}$} & \multicolumn{2}{|c|}{$\begin{array}{l}\text { 95\% Confidence } \\
\text { Interval for Mean }\end{array}$} \\
\hline & & & & $\begin{array}{l}\text { Lower } \\
\text { Bound }\end{array}$ & $\begin{array}{l}\text { Upper } \\
\text { Bound }\end{array}$ \\
\hline $18-29$ & 85 & 17.964 & 4.004 & 17.10 & 18.82 \\
\hline $30-39$ & 60 & 18.250 & 3.689 & 17.29 & 19.20 \\
\hline $40-49$ & 36 & 19.000 & 4.021 & 17.63 & 20.36 \\
\hline $50 \&$ above & 7 & 18.285 & 5.964 & 12.76 & 23.80 \\
\hline Total & 188 & 18.266 & 3.976 & 17.69 & 18.83 \\
\hline
\end{tabular}

TABLE. IX. SUMMARY OF HYPOTHESES RESULTS

\begin{tabular}{|c|c|c|c|}
\hline $\mathbf{N}$ & Hypothesis & $\begin{array}{l}\text { Results } \\
\text { (Accept/Reject) }\end{array}$ & $\begin{array}{l}\text { Relationship } \\
\text { Strength }\end{array}$ \\
\hline H1a & $\begin{array}{l}\text { Technical factors are } \\
\text { positively related to } \\
\text { perceived usefulness }\end{array}$ & Accept & $\begin{array}{l}\text { Strong } \\
0.761\end{array}$ \\
\hline $\mathrm{H} 1 \mathrm{~b}$ & $\begin{array}{l}\text { Technical factors are } \\
\text { positively related to } \\
\text { perceived ease of use }\end{array}$ & Accept & $\begin{array}{l}\text { Strong } \\
0.713\end{array}$ \\
\hline $\mathrm{H} 2 \mathrm{a}$ & $\begin{array}{l}\text { Demographic factors have } \\
\text { influence on perceived } \\
\text { usefulness }\end{array}$ & Reject & No influence \\
\hline $\mathrm{H} 2 \mathrm{~b}$ & $\begin{array}{l}\text { Demographic factors have } \\
\text { influence on perceived ease } \\
\text { of use }\end{array}$ & Reject & No influence \\
\hline $\mathrm{H} 3 \mathrm{a}$ & $\begin{array}{l}\text { Social influence is positively } \\
\text { related to perceived } \\
\text { usefulness }\end{array}$ & Accept & $\begin{array}{l}\text { On average } \\
0.491\end{array}$ \\
\hline $\mathrm{H} 3 \mathrm{~b}$ & $\begin{array}{l}\text { Social influence is positively } \\
\text { related to perceived ease of } \\
\text { use }\end{array}$ & Accept & $\begin{array}{l}\text { Midum } \\
0.423\end{array}$ \\
\hline $\mathrm{H} 4 \mathrm{a}$ & $\begin{array}{l}\text { Political factors are positively } \\
\text { related to perceived } \\
\text { usefulness }\end{array}$ & Accept & $\begin{array}{l}\text { Weak } \\
0.279\end{array}$ \\
\hline $\mathrm{H} 4 \mathrm{~b}$ & $\begin{array}{l}\text { Political factors are positively } \\
\text { related to perceived ease of } \\
\text { use }\end{array}$ & Accept & $\begin{array}{l}\text { Weak } \\
0.315\end{array}$ \\
\hline H5 & $\begin{array}{l}\text { Perceived quality is } \\
\text { positively related to technical } \\
\text { factors }\end{array}$ & Accept & $\begin{array}{l}\text { Strong } \\
0.731\end{array}$ \\
\hline H6 & $\begin{array}{l}\text { Perceived usefulness is } \\
\text { positively related to e- } \\
\text { participation level }\end{array}$ & Accept & $\begin{array}{l}\text { Strong } \\
0.702\end{array}$ \\
\hline H7 & $\begin{array}{l}\text { Perceived ease of use is } \\
\text { positively related to e- } \\
\text { participation level }\end{array}$ & Accept & $\begin{array}{l}\text { On average } \\
0.650\end{array}$ \\
\hline
\end{tabular}

\section{DISCUSSION}

The research questions are highlighted together with their responses in the light of conducted study, as follows:

1) What are the factors affecting e-participation in Kuwait?

The research result shows that the following are the factors that influence the citizens and residents' e-participation in Kuwait e-government:

a) Technical Factors refer to the website design and content, channels of communication, and infrastructure. The technical factors have a strong positive relationship with perceived usefulness (PU) and perceived ease of use (PEU).

b) Social Influence is the persuasive influence people have on one another. It has an average relationship on PU and PEU.

c) Political Factors are related to the level of trust in government, government commitment and the political party affairs. The research found that political factors have a weak relationship on PU and PEU.

2) Does Kuwait have a low level of e-participation in egovernment portal and Why? 
As stated in the questionnaire, Kuwait has a low level of eparticipation. Only $53.15 \%$ of the respondents used egovernment portal, but the sample size should have to be bigger to get better results.

3) How to attract citizens to participate in e-government portal?

Attracting citizens to use the e-government portal is essential. In the questionnaire, citizens mentioned some of the reasons why they did not use the portal. Most of the reasons mentioned are about the website contents, privacy, availability of services, and information the portal provide. This means that the government must communicate with citizens, know their requirements, and reflect accordingly the changes and improvements in the portal.

To make people use e-government portal, the services must be sincerely useful to the targeted users. They must be efficient and meet citizen's specific requirements. For an effective participation in e-government portal, attractive awareness campaigns must be launched directing potential users appropriately to notify them about the real benefits they would gain out of participating in e-government.

\section{CONCLUSION}

Most governments provide online information and services to their citizens and residents which is very common in the world nowadays. This research study aimed to identify the critical factors that led to participate in e-government in Kuwait. The result showed that technical factors, political factors, social influence, perceived quality, perceived ease of use, and perceived usefulness influence citizens' intention to participate in e-government portal.

The results from the statistical analysis concluded that a large portion of people $46.85 \%$ do not use the e-government portal. It is important to mention that the results, in this study, are helpful for decision makers to understand the citizen's needs and requirements. The proposed research model has proved to be a useful guideline that would support egovernment strategy in Kuwait.

Although the developed model and its implementation are effective, yet there is a room to extend the study further. As a future work, one can consider the followings: Using a larger population sample; extend the number of factors in the model to include, for example, security and trust; and study the factors influencing each level of e-participation framework, which are e-information, e-consultation, and e-decisionmaking.

\section{REFERENCES}

[1] Digitales.oesterreich.gv.at., "What is e-Government?", 2015. Retrieved Oct 2017, from Digital Austria: REF: http://www.digitales.oesterreich. gv.at/ site/6506/default.aspx.

[2] Russell, T. Electronic Government Barriers and Benefits as Perceived by Citizens Who Use Public. Walden University, 2013.

[3] West, D. M. "E-government and the Transformation of Service Delivery and Citizen Attitudes", Public Administration Review, Vol. 64, No. 1, pp. 15-27, 2004.
[4] Palvia, S. C. J. and Sharma, S. S., "E-government and E-governance: Definitions/Domain Framework and Status around the World". Foundations of E-government, International Conference on Egovernance, USA: Computer Society of India, 2007.

[5] Peristeras, V., Mentzas, G., Tarabanis, K. A., and Abecker, A. "Transforming E-government and E-participation through IT", Guest Editors' Introduction, IEEE Intelligent Systems, September/October, 2009, pp. 14-19.

[6] Smith S. and Dalakiouridou, E. "Contextualising Public (e)Participation in the Governance of the European Union", European Journal of ePractice, No. 7, pp. 1-9, 2009.

[7] UN E-government Survey in the News, (n.d.). Retrieved from The United Nations: http://unpan3.un.org/egovkb/egovernment_overview/ eparticipation.htm, 2018.

[8] Loulis, E., Macintosh, A., and Charalabidis, Y., "E-participation in Southern Europe and the Balkans: Issues of Democracy and Participation Via Electronic Media”, Routledge, 2013

[9] Delakorda, S., "E-participation". e-Democracy Conference. Institute for Electronic Participation, 2011.

[10] Ekelin, A., The Work to Make eParticipation Work. Doctoral Dissertation Thesis, Blekinge Institute of Technology, SWEDEN, 2007.

[11] Macintosh, A., "Characterizing E-participation in Policy-Making". Proceedings of the 37th Hawaii International Conference on System Sciences, pp. 1-10, 2004.

[12] Lamrabat, A. and Jiang, N., "E-participation: Empowering People through Information Communication Technologies (ICTs)", AideMémoire, Expert Group Meeting, United Nations Department of Economic and Social Affairs Division for Social Policy and Development, 2013.

[13] Millard, J., Nielsen, M. M., Waren, R., Smith, S., Macintosh, A., "European eParticipation Summary Report". European Commission, pp. 7-12, 2009.

[14] UN "E-government Survey, 2018" E-government for the Future We Want, Department of Economic and Social Affairs, United Nations, New York, 2018.

[15] Reddick, C. G., "Comparing citizens' use of e-government to alternative service channels", International Journal of Electronic Government Research (IJEGR), Vol. 6, No. 2, pp. 54-67, 2009.

[16] Daniele M. Nascimento, "Information flows in e-participation applications implications in government service-delivery in Brazil", International Conference on Information Society (i-Society), Pages: 51 $52,2016$.

[17] UN, "Singapore's Experience: Initiatives to promote e-participation", INFOCOMM Development Authority of Singapore, E-participation: Empowering People through Information Communication Technologies (ICTs), 24-25 July 2013.

[18] Bwalya, K. J. (2009) "Factors affecting adoption of e-government in Zambia," The Electronic Journal of Information Systems in Developing Countries, Vol. 38, pp. 1-13.

[19] Khoirunnida; A. Nizar Hidayanto; Betty Purwandari; Riski Yuliansyah; Meidi Kosandi, "Factors influencing citizen's intention to participate in e-participation: Integrating Technology Readiness on Social Cognitive Theory", ICIC Second International Conference on Informatics and Computing, Pages: 1-7, 2017.

[20] Stoiciu, A., "Strengthening e-participation: Overcoming Obstacles for Better Consultation Mechanisms". E-participation Empowering People Through ICTs. Geneva : IMDD, 2013.

[21] Ali, H. and Ali, T., "E-participation: an investigation of Government Readiness in the Kingdom of Bahrain", Journal of e-government Studies and Best Practices, IBIMA Publishing, (2015), pp. 1-13, 2015.

[22] Bernd W. Wirtz, Peter Daiser \& Boris Binkowska, E-participation: A Strategic Framework, International Journal of Public Administration, 41:1, 1-12, 2018. DOI: 10.1080/01900692.2016.1242620.

[23] Colesca, S. E., and Dobrica, L., "Adoption and Use of e-government Services: The Case of Romania", Journal of Applied Research and Technology. Vol. 6. pp.204-217, 2008. 
[24] Ahmad, M. O., Markkula, J., Oivo, M. (2013) "Factors affecting egovernment adoption in Pakistan: a citizen's perspective", Transforming Government: People, Process and Policy, Vol. 7, No. 2, pp. 225-239, 2013.

[25] AlAwadhi S. and Morris, A., "Citizen Awareness to e-government
Services for Information Personalization", Journal of Software, Vol 4, No 6, pp. 584-590, 2009.

[26] Aljazzaf, Zainab M.. "Evaluating Trust in E-government: The case of Kuwait." $5^{\text {th }}$ International Conference on Computer and Technology Applications (ICCTA) 2019 . DOI:10.1145/3323933.3324073.

APPENDIX 1

Table X presents the research questionnaire. The questionnaire presents the factors and their criteria.

TABLE. X. RESEARCH QUESTIONNAIRE

\section{Perceived Quality}

The information in the portal is useful

The information in the portal is up to date

The information in the portal is easy

The information in the portal is accurate

The portal provides information in an adequate level of detail

The interaction with the portal is clear and comprehensive

The design is appropriate for the type of the website for e-government

The portal provides a positive experience

It is safer to complete the transactions on the portal

I feel that my personal information is secure on the portal

\section{Political Factors}

I use services in the e-government portal because I trust the government

I use e-government portal because my political party allows me to do

Lack of implementation of policies leads to low level of e-participation

Changes in the local political events changed my view about e-participation

\section{Technical Factors}

Registration in the portal is easy

Using the e-government portal is easy

The e-government portal involves many important services

The services provided online make the procedures easier and simple

The government services provided online are of high quality

Weak internet in Kuwait prevents citizens from the portal usage

\section{Social influence}

I suggest using the e-government portal to others

I use the e-government portal because my family uses it

I use the e-government portal because my friends use it

I use the e-government portal because important people such as celebrities use it

I use the e-government portal because my work colleagues use it

\section{Perceived Usefulness}

The portal enables me to accomplish tasks more quickly

The portal enhances my effectiveness on doing my job

I can easily search and navigate in the e-government portal

I find the suitable help I expect

Access to the services is provided for citizen, resident, \& person with disabilities

\section{Perceived Ease of Use}

I rarely make errors when using the portal

I rarely become confused when using the portal

I found the e-government portal flexible to interact with

Overall, I found e-government portal ease to use

My interface with e-government portal was clear and understandable

\section{Intention to participate}

I intend to use e-government portal because I found it useful

I intend to use e-government portal because I found it easy

I intend to use e-government portal in the future 